\title{
(-⿶凵⿴囗十)
}

Citation:

Morgan, SJ (2018) John Deakin Heaton and the 'elusive civic pride of the Victorian middle class'. Urban History, 45 (4). pp. 595-615. ISSN 0963-9268 DOI: https://doi.org/10.1017/S096392681700058X

Link to Leeds Beckett Repository record:

https://eprints.leedsbeckett.ac.uk/id/eprint/4046/

Document Version:

Article (Accepted Version)

The aim of the Leeds Beckett Repository is to provide open access to our research, as required by funder policies and permitted by publishers and copyright law.

The Leeds Beckett repository holds a wide range of publications, each of which has been checked for copyright and the relevant embargo period has been applied by the Research Services team.

We operate on a standard take-down policy. If you are the author or publisher of an output and you would like it removed from the repository, please contact us and we will investigate on a case-by-case basis.

Each thesis in the repository has been cleared where necessary by the author for third party copyright. If you would like a thesis to be removed from the repository or believe there is an issue with copyright, please contact us on openaccess@leedsbeckett.ac.uk and we will investigate on a case-by-case basis. 


\section{John Deakin Heaton and the 'elusive civic pride of the Victorian middle class'}

John Deakin Heaton was a Leeds Doctor and leading member of what George Kitson-Clark dubbed the 'Leeds Elite'. ${ }^{1}$ Today, he is little remembered beyond, or even within, his native town, though urban historians may know him as one of the principal progenitors of the Leeds Town Hall, as described in Asa Briggs's Victorian Cities. ${ }^{2}$ More recently, Heaton has caught the imagination of Tristram Hunt, media historian, some-time Labour frontbencher and now director of the Victoria \& Albert Museum, who wrote Heaton's entry for the Oxford Dictionary of National Biography. ${ }^{3}$ Heaton is one of only two subjects on whom Hunt has written for the ODNB, the other being Edinburgh sanitary reformer Hector Gavin. ${ }^{4}$ Both were notable for their civic contribution and for their relative obscurity; they were chosen to exemplify what Hunt describes as the 'elusive civic pride of the Victorian middle class', a quality which he celebrates in his book Building Jerusalem and which is apparently keen to re-invigorate as part of his vision for Britain's urban future. ${ }^{5}$

It is this notion of middle-class civic pride which this article aims to interrogate and unpick. In Britain, civic pride has been seen as a particular feature of the post-reform era when many rapidly expanding urban/industrial centres gained parliamentary representation, or went on to develop independent civic institutions for the first time through campaigns for Incorporation under the 1835 Municipal Reform Act. Leeds, unlike Manchester or Bradford, already had a charter. Here the effect of the Act was to take the old closed Corporation, dominated by a self-selecting oligarchy of Anglican merchants, and open it up to a new breed

\footnotetext{
${ }^{1}$ G. Kitson Clark, 'The Leeds Elite', University of Leeds Review, 17 (1975), 232-58; the formation of an 'eliteled' middle class in Leeds is fully developed in R. J. Morris, Class, Sect and Party: The Making of the British Middle Class (Manchester, 1990). In this article use of the term 'elite' follows that of Kitson Clark and R. J. Morris to refer to the leading families of the town, most of whom derived their wealth from the classic 'bourgeois' pursuits of trade or manufacturing rather than landownership (though this did not preclude smallscale landowning), but whose sheer wealth and public status distinguished them from the main body of the middle class, making them the principal power-brokers of the town in this period.

${ }^{2}$ A. Briggs, Victorian Cities (London, 1963), chapter 4, with Heaton's role detailed at 159-66.

${ }^{3}$ T. Hunt, 'Heaton, John Deakin (1817-1880)', Oxford Dictionary of National Biography, Oxford University Press, May 2006; online edn, May 2007 [http://www.oxforddnb.com/view/article/94166, accessed 1 June 2015]. ${ }^{4}$ T. Hunt, 'Gavin, Hector (1815-1855)', Oxford Dictionary of National Biography, Oxford University Press, May 2006; online edn, May 2009 [http://www.oxforddnb.com/view/article/94168, accessed 27 July 2015].

${ }^{5}$ T. Hunt, Building Jerusalem: The Rise and Fall of the Victorian City (London, 2004).
} 
of nonconformist manufacturers. ${ }^{6}$ These two groups, fractured as they were by political, religious and economic divisions, formed the nucleus of the 'Leeds Elite': a familiar story of the assimilation of 'old' and 'new' money replicated over the century in other cities, including 1880s New York. ${ }^{7}$ However, the development of a fully-fledged notion of 'civic pride' arguably owed much to the efforts of a cadre of educated men, including doctors, lawyers and clergymen, possessing the requisite cultural capital and motivated by aesthetic and cultural aspirations above and beyond the desire for making money. ${ }^{8}$ To these we can add a set of cultural brokers, in Leeds notably the editors of local newspapers such as Christopher Kemplay of the Leeds Intelligencer and the two Edward Baines (senior and junior) of the Leeds Mercury, who could promote and lobby for those aspirations; and local architects such as Richard Chantrell, Cuthbert Brodrick and George Corson, able to render them in mortar and stone. ${ }^{9}$

Civic pride itself was embodied in the formation of elite cultural institutions such as Literary and Philosophical societies, the construction of prestige buildings for commerce or the administration of local government and justice, and a concern for the poorer members of society in the form of medical charities and the provision of public parks. ${ }^{10}$ In British and American cities, it was enacted through rituals such as civic processions which could include the respectable working classes in the form of trade and friendly societies, at the same time as

\footnotetext{
${ }^{6}$ R. Wilson, Gentleman Merchants: The Merchant Community in Leeds, 1700-1830 (Manchester, 1971).

${ }^{7}$ S. Beckert, Monied Metropolis: New York City and the Consolidation of the American Bourgeoisie, 1850-1896 (Cambridge, 1993), 244-9.

${ }^{8}$ P. Corfield, Power and the Professions in Britain 1700-1850 (London \& New York, 1995); R. Gray, 'The Platform and the Pulpit: Cultural Networks and Civic Identities in Industrial Towns, c. 1850-70', in A. Kidd and D. Nicholls (eds.), The Making of the British Middle Class? Studies of Regional and Cultural Diversity Since the Eighteenth Century (Stroud, 1998), 130-47.

${ }^{9}$ D. Read, Press and People, 1790-1850: Opinion in Three English Cities (London, 1961); C. Webster (ed.), Building a Great Victorian City: Leeds architects and architecture, 1790-1914 (Huddersfield, 2011).

${ }^{10} \mathrm{~J}$. Wolff and J. Seed (eds.), The Culture of Capital: Art, Power and the Nineteenth-Century Middle Class (Manchester, 1988); S. Gunn, Public Culture of the Victorian Middle Class: Ritual and Authority in the English Industrial City 1840-1914 (Manchester, 2000), 50-3; H. Conway, People's Parks: The design and development of Victorian Parks in Britain (Cambridge, 1991), 141-54; A. Wilson, “"The Florence of the North"? The Civic Culture of Liverpool in the Early Nineteenth Century' and K. Hill, “"Thoroughly Embued with the Spirit of Ancient Greece": Symbolism and Space in Victorian Civic Culture', both in A. Kidd and D. Nicholls (eds.), Gender, Civic Culture and Consumerism: Middle-Class Identity in Britain, 1800-1940 (Manchester, 1999), 3446 and $99-111$.
} 
they reinforced urban hierarchies through orders of march and strict attention to rules of precedence. ${ }^{11}$ Such things were intended to enhance the standing of a town in the eyes of outsiders, while providing moral lessons to inhabitants, particularly those lower down the social scale. As the century wore on, the city of Birmingham famously pioneered the 'civic gospel', whereby the moral and legal responsibilities of the municipal council were broadened to encompass the physical wellbeing of the inhabitants and the provision of basic amenities such as gas and water. ${ }^{12}$ On the more negative side, as Briggs acknowledged, civic pride was also about civic rivalry: a form of one-upmanship expressed in the diversity of amenities, the relative dimensions of concert halls and clock towers, and the competitive honouring of national heroes. ${ }^{13}$ Above all, civic pride has been seen as both an important expression of the identity of an urban middle class, and a means of cementing its dominance in local affairs. ${ }^{14}$

Studies of civic pride usually start with the institutions, rituals, buildings or policies which gave it form and expression, before moving to discuss the groups whose shared values those institutions, rituals, buildings or policies expressed. Individuals feature as the instruments or champions of this collective will; or, as in the case of nationally important figures like Joseph Chamberlain, their involvement in local civic affairs is highlighted as part of their progress to greater things. ${ }^{15}$ However, in John Deakin Heaton we have an opportunity to study civic pride as part of the fabric of a relatively unknown individual's life, activities and aspirations, rather than as a somewhat inchoate group attribute or a staging post to wider fields of action. The aim of this article is therefore to trace the different sources and

\footnotetext{
${ }^{11}$ S. Gunn, 'Ritual and civic culture in the English industrial city, c. 1835-1914', in R. J. Morris and R. H. Trainor (eds.), Urban Governance: Britain and Beyond since 1750 (Aldershot, 2000), 226-41; S. Morgan, A Victorian Woman's Place: Public Culture in the Nineteenth Century (London, 2007), 164-70; M. Ryan, Civic Wars: Democracy and Public Life in the American City during the Nineteenth Century (Berkeley and Los Angeles, 1997), chapter 2.

${ }^{12}$ Briggs, Victorian Cities, chapter 5; E. P. Hennock, Fit and Proper Persons: ideal and reality in nineteenthcentury urban government (London, 1973).

${ }^{13}$ Briggs, Victorian Cities, 153.

${ }^{14}$ L. Purbrick, 'The bourgeois body: civic portraiture, public men and the appearance of class power in Manchester, 1838-50', in Kidd and Nicholls, Gender, Civic Culture and Consumerism, 81-98; M. Hewitt, The Emergence of Stability in the Industrial City: Manchester, 1832-67 (Aldershot, 1996), 82-91; R.J. Morris, 'A Year in the Public Life of the British bourgeoisie', in R. Colls and R. Rodger (eds.), Cities of Ideas: Civil Society and Urban Governance in Britain, 1800-2000 (Aldershot, 2004), 121-43.

${ }^{15}$ Briggs, Victorian Cities, 231.
} 
expressions of Heaton's civic pride, to see what it consisted of and the extent to which it sprang from or was in conflict with other parts of his identity as a son, father, doctor, educator and leading Anglican: a member of the Leeds elite, who owed his position near the apex of Leeds society to his professional, familial and religious affinities and status. From the outset, we should note that Heaton aspired primarily to influence rather than power. $\mathrm{He}$ stood only once for elected office (to the School Board), and then reluctantly. Generally, he preferred to work with the apparatus of local government, rather than within it. A central concern of this article is therefore with the means by which Heaton attempted to exert such influence, using social, associational or institutional connections and letters to the press (both avowed and anonymous) to make his points.

\section{The Heaton Journals}

That we can attempt such a detailed study of this largely obscure individual is due in no small measure to the unique set of journals that he left behind. ${ }^{16}$ These seven leather-bound volumes were rescued, from obscurity and possible destruction, by the late Dorothy Payne of the Yorkshire Archaeological Society. ${ }^{17}$ Heaton began to keep them in May 1859, writing up his life to that point and then keeping them up to date until just before his death in 1880 . They were apparently written up from a daily diary which has not survived, but which enabled his wife Fanny to complete the journal after Heaton's death, by which point Heaton's journal-writing was about six months in arrears. The journals are a pretty full record of Heaton's public and private activities, promiscuously mixing accounts of public meetings and dinners, appointments to committees and various philanthropic and professional engagements, with family excursions, continental tours and acerbic comments on friends, relations and acquaintances: including strictures on his son's feckless behaviour at Cambridge University. ${ }^{18}$ It was these journals, suitably edited and bowdlerized, which formed the basis of Thomas Wemyss Reid's biography of Heaton, published shortly after his death at Fanny's request, explaining why this was (somewhat misleadingly) titled as a

\footnotetext{
${ }^{16}$ Heaton Papers, Brotherton Library Special Collections, YAS-UoL D465 box 1. The folios of the entirety of volumes one to three and the majority of volume four have been numbered in pencil by a member of the Yorkshire Archaeological Society. These folio numbers have been used in the references here. Where these are absent, Heaton's dates have been used as a guide to the location of information in the journals.

${ }^{17}$ See D. Payne and B. Payne, 'Extracts from the Journals of John Deakin Heaton, M.D., of Claremont, Leeds', Publications of the Thoresby Society, 53 (1973), 93-153.

${ }^{18}$ E.g. Journals, iv. 24 March 1876.
} 
'memoir'. ${ }^{19}$ In passing, the author noted that the journals, though full of reference to Heaton's public activities, were primarily a record of his domestic life: a hint taken up by John Tosh, who used them to good effect in his study of middle-class masculinity. ${ }^{20}$ More recently, they have yielded information on the work of Heaton's wife Fanny and sister Ellen in promoting the cause of female education and political rights and participation in a range of philanthropic, cultural and educational activity in their native town. ${ }^{21}$

In conjunction with the minute books and annual reports of local societies and committees, and newspaper reports of public meetings, the journals allow us to build a comprehensive picture of Heaton's public activities, particularly during the final three decades of his life when he was a well-established member of the Leeds elite with important family, professional, religious and associational connections to local opinion formers. ${ }^{22}$ They also allow us a fuller insight into the levers of influence which Heaton used to register his views on matters of civic improvement and display. While his success as promoter of the Town Hall is well known, there were other instances where Heaton's voice was ignored, or where conflicts of interest prevented him from acting openly. In these instances, the journals throw light on episodes which barely register in official sources. In particular, it is the comments Heaton makes in his journals about his public duties, his co-workers, and the various honours with which he was bestowed, which reveal the true complexity of his motivations in supporting local associations, institutions and initiatives for civic improvement.

The attempt to map the complete range of Heaton's public activities has been facilitated by the Heaton Map Project at Leeds Beckett University, which has used the journals to map key sites connected with Heaton and his family as part of a walking tour of

\footnotetext{
${ }^{19}$ T. Wemyss Reid, Memoir of J.D. Heaton MD (London, 1883).

${ }^{20}$ Reid, J. D. Heaton, 118-19; J. Tosh, A Man's Place: Masculinity and the Middle-Class Home in Victorian England (New Haven, 1999).

${ }^{21}$ Morgan, A Victorian Woman's Place.

${ }^{22}$ Heaton's obituary in the British Medical Journal listed many of the positions he held at or shortly before his death: member of the Council of the Leeds Philosophical and Literary Society; chairman of the Yorkshire Board of Education; member of first School Board; Justice of the Peace for the West Riding of Yorkshire; trustee of the Pious Uses Trust; member of the Board of Management of Leeds Church Extension Society; honorary physician to the Tradesman's Benevolent Institution, the Unmarried Women's Benevolent Institution and the Leeds Town Mission; trustee of the patronage of the livings of St George's, St Andrew's and St Michael's Buslingthorpe; honorary secretary of the Leeds Improvement Society; chair of the Council of the Yorkshire College: BMJ, 10 April 1880, 570.
} 
the Victorian city. ${ }^{23}$ This article will be interactive with the Heaton Map, with links to key sites, buildings and institutions as they are mentioned in the text. As well as being an effective piece of public history, designed to reconnect visitors to and residents of Leeds with a forgotten figure from the city's past, the process of constructing the map has also revealed some of the patterns of Heaton's public activities. For instance, the types of organisation with which he was involved can be broken down into medical (the various Leeds hospitals and the Leeds Medical School), educational (the Medical School, the Yorkshire Board of Education, the Yorkshire College, the Leeds School Board, Leeds Grammar School), religious/Anglican (St George's Church and its satellites, the Church Extension Society) and cultural (the Philosophical and Literary Society; the Leeds Library). Spatially, the map shows the concentration of Heaton's activities in west-central Leeds, with rare forays into the working-class east of the city via his work for the School Board and church extension society, and to the south of the river with regard to family links to the Hunslet area. Largely though, Heaton's world centred on Little Woodhouse, to which he moved in 1856, partly to escape from the increasingly smoke-ridden area around Park Square. There, his sister, noted PreRaphaelite patron and feminist Ellen Heaton, was a near neighbour on Woodhouse Square. ${ }^{24}$ In the following decade this area also became the centre of Heaton's professional activities as key medical institutions followed Heaton's trajectory, starting with the Women's and Children's Hospital in 1860, the Leeds Medical School in 1865 and Leeds General Infirmary in 1869. Between the women's hospital and the infirmary was St George's church, where Heaton was a trustee and where he and his wife are buried, while the other end of Great George Street became the centre of local government with the construction of the Town Hall (1853-8) and Municipal Buildings (1878-84).

\section{A 'leading citizen' of Leeds}

In her book Borderline Citizens, Kathryn Gleadle explores the different routes by which Victorian women could enter the public sphere and cultivate public subjectivities. These

\footnotetext{
${ }^{23}$ www.heatonmap.mobi This project was undertaken in conjunction with the Humanities Research Institute at the University of Sheffield, with the sponsorship of the Centre for Culture and the Arts, Leeds Beckett University.

${ }^{24}$ D. S. Macleod, 'Heaton, Ellen (1816-1894)', Oxford Dictionary of National Biography, Oxford University Press, 2004; online edn, May 2007 [http://www.oxforddnb.com/view/article/62814, accessed 1 June 2015].
} 
included the mobilisation of family name and connections, activity in the 'parochial sphere' of face-to-face contact, the development of acknowledged expertise in a given field, and civic engagement via associational life. ${ }^{25}$ While providing a valuable approach to women's history, this model also has much to recommend it in explaining how a relatively diffident man like Heaton was able to achieve public prominence and how he was able to develop his own self-conception as one of Leeds's 'leading citizens'.

To take family first, in his journal Heaton traced his family's connection with Leeds back to his grandfather's purchase of a small estate in Hunslet, to the south of Leeds, in 1783. This became the core of the family's landholding in the area, the moiety of which Heaton purchased from his uncle William following his father's death. ${ }^{26}$ More importantly, in 1805 his father (also John) came into possession of the bookshop and stationery business of John Binns, former owner of the Leeds Mercury, which he had managed since 1791. Heaton records that his father's shop was a meeting place for educated gentlemen from Leeds and beyond. ${ }^{27}$ It was sufficiently successful to allow Heaton senior, on his retirement in 1827 , to purchase a house on Park Square, a genteel address that had been part of the first attempt to provide Leeds with a refined Georgian 'West End' ${ }^{28}$ In 1844 Heaton senior purchased his son's first house on nearby East Parade when he returned from his medical education at University College London (after an abortive stint at Cambridge), allowing him to set up in private practice and to undertake teaching duties at the adjoining Leeds School of Medicine. ${ }^{29}$ Unlike many provincial medical professionals, Heaton was not a 'marginal man': instead, his ancestry connected him firmly to the Leeds elite. ${ }^{30}$

Both Heaton's sense of public duty and pattern of public engagement can therefore be traced in part to filial piety and a desire to maintain his family's leading position in the town,

\footnotetext{
${ }^{25}$ K. Gleadle, Borderline Citizens: Women, Gender and Political Culture in Britain, 1815-1867 (Oxford, 2009); Gleadle's concept of the 'parochial sphere' is influenced by L. Lofland, The Public Realm: exploring the city's quintessential social territory (Hawthorne, NY, 1998).

${ }^{26}$ Journals, i. fo. 107.

${ }^{27}$ Reid, J.D. Heaton, 54-6.

${ }^{28}$ Reid, J.D. Heaton, 57, 59. This attempt was ultimately stymied by the smoke of the works proliferating along the river Aire further west: Maurice Beresford, East End, West End: the face of Leeds during urbanisation 16841842 (Leeds, 1988), 286-303.

${ }^{29}$ For Heaton's education, Reid, J.D. Heaton, 64-80.

${ }^{30}$ I. Inkster, 'Marginal Men: Aspects of the social role of the medical community in Sheffield, 1790-1850', in J. Woodward and D. Richards (eds.), Health Care and Popular Medicine in Nineteenth Century England, 128-63.
} 
particularly after his father's sudden death in $1852 .{ }^{31}$ That year, Heaton replaced his father on the managing committee of the Leeds General Cemetery Company, whose shareholders included representatives of most of the town's leading families. ${ }^{32}$ In 1854 he was elected to the committee of the Leeds Library (where his father had also been a shareholder), and appointed a director of the Leeds Gas Company. ${ }^{33}$ Moreover, the journals also reveal Heaton's desire to memorialise his ancestors. When the rebuilding of $\underline{\text { Hunslet Parish Church }}$ required the removal of his grandparents' headstones, Heaton paid for a commemorative window to be installed in the new structure. ${ }^{34}$ Similarly, when George Gilbert Scott's new Infirmary building neared completion, Heaton paid for a commemorative window dedicated to his mother and father to be installed in the chapel, as his father had been 'for about quarter of a century a regular attendant at the Weekly Board'. ${ }^{35}$ Later, he installed a gilded brass plate to their memory beneath the window. ${ }^{36}$ The memorialisation of family connections with institutions and sacred spaces within Leeds was clearly important to Heaton.

Sadly, Heaton found himself with less cause to celebrate the achievements of the next generation. Heaton's comments reveal a growing disappointment with his sons, particularly the eldest, (John) Arthur Dakeyne Heaton. Himself educated at Leeds Grammar School, Leeds School of Medicine and UCL, Heaton simply could not understand why the sons he sent to Rugby, Charterhouse and Cambridge were not interested in living the lives of provincial professionals: a striking illustration of Martin Weiner's thesis of the 'gentrification' of the Victorian middle-class through exposure to the public schools and ancient universities. ${ }^{37}$ Heaton's sons eventually entered the law, but never returned to live in Leeds. Fanny's will, drawn up in 1892, lists Arthur, as a Barrister in Rangoon, while Beresford Rimington Heaton (Berry), was a solicitor at New Square, Lincoln's Inn. ${ }^{38}$ Berry eventually found distinction as High Sheriff of Surrey in 1916, and became a governor of

\footnotetext{
${ }^{31}$ Preston Guardian, 23 July 1852.

${ }^{32}$ Minutes of the Leeds General Cemetery Company, Leeds University Library Special Collections MS 421/33 fo. 62; M. Beresford, Walks Round Red Brick, $2^{\text {nd }}$ edition (Leeds, 2012), p. 44.

${ }^{33}$ Minute Books of the Leeds Library 1800-1879, 5 June 1854: Leeds Library Archive; Journals, i. fo. 133.

${ }^{34}$ Journals, ii., fos. 50-2. The church was rebuilt again in 1974 and the window lost.

35 Journals, ii. fo. 146.

${ }^{36}$ Journals, iv. 3 July 1875.

${ }^{37}$ M. J. Weiner, English Culture and the Decline of the Industrial Spirit 1850-1980 (London, 1981), 16-24.

${ }^{38}$ Will of Fanny Heaton, proved 7 Dec. 1893.
} 
Leeds University, which he endowed with a scholarship in his father's name. ${ }^{39}$ However, the journals reveal Heaton taking solace in his daughters, Helen, Marian (May) and Lucy (Loo), who were all involved in local philanthropic and educational work, including the RSPCA, the $\underline{\text { Yorkshire School of Cookery (a forerunner of Leeds Beckett University), and the Leeds }}$ Blind, Deaf and Dumb Institution. ${ }^{40}$ Here they benefited from the guidance and example of their mother Fanny and aunt Ellen. ${ }^{41}$ Fanny was involved in the establishment of the Leeds Girls High School in 1876 and persuaded Heaton to allow their Loo to work there as a salaried teacher, though he eventually forced her to resign after two years of gossip from neighbours. ${ }^{42}$

Filial pride alone does not explain Heaton's rise to local prominence. Returning to Gleadle's model, Heaton's public standing depended to a great extent on his own claims to expertise as a medical man, specifically a university-educated physician with an MD from University College, which gave him an entrée to many key civic institutions. His journals reveal the progress of his career through the proliferating medical institutions of Leeds. He taught at the Leeds Medical School, being appointed to the Council in 1844, and held positions at most of the hospitals, including (in the early 1850s) simultaneous posts at the General Infirmary, the Dispensary and the House of Recovery, and later the Women's and Children's Hospital. ${ }^{43}$ At one point he was sole physician at the Dispensary, a situation only rectified after he tendered his resignation. ${ }^{44}$

These appointments cemented Heaton's reputation as one of Leeds's foremost medical men, giving him intellectual and public credibility in the locality and lending weight

\footnotetext{
39 'Former High Sheriff', Surrey Advertiser, 8 June 1940; Will of Beresford Rimington Heaton, proved 21
} August 1940, clause 28. This still exists as the John Deakin Heaton Scholarship for Applied Health. He also left money to the Leeds Infirmary, the Leeds Unmarried Women's Benevolent Society and the Meanwood Convalescent Home, the latter two charities in memory of his mother.

40 Journals, v. 28 Jan. 1878; LM 30 Jan. 1878; Minutes of the Yorkshire School of Cookery, Leeds Branch, fos. 146-7, West Yorkshire Archive Service, Leeds, WYL 5045/28.

${ }^{41}$ For Fanny’s public activities, see Morgan, A Victorian Woman's Place, 191-6.

42 Journals v. 22 Jan. 1877; vi. [n.d.] Dec. 1878.

${ }^{43}$ S. T. Anning, The History of Medicine in Leeds (Leeds: W. S. Maney \& Sons, 1980); S. T. Anning and W. K. J. Walls, A History of the Leeds School of Medicine (Leeds, 1982). Heaton's journal never mentions his position as Physician to the Women's and Children's Hospital, from 1869-1880, but this is confirmed from the Annual Reports and A. M. Claye, A Short History of the Hospital for Women at Leeds, 1853-1953 (Leeds, n.d. [1953]), 28.

${ }^{44}$ Anning, History of Medicine in Leeds, 91-2. 
to his views on subjects such as public health and education. Moreover, Heaton also forged a reputation for cultured cosmopolitanism through his travels on the continent and membership of national learned societies, particularly the British Association for the Advancement of Science. ${ }^{45}$ He was thus embedded not just in a national, but a European bourgeois culture. ${ }^{46}$ Heaton's journal entries for his European tours devote much space to architecture, both ecclesiastical and secular. His famous lecture on the necessity of including a clock tower on the new Leeds Town Hall drew on his observations of the grandeur of such structures in Bruges and Ghent. ${ }^{47}$ He made a connection between great civic architecture and well run civic polities, which he attributed at least in part to the uplifting moral example which the former provided to the citizenry.

Together with his family connections, his professional status and reputation as a cultured traveller bolstered Heaton's claims to inclusion in the 'Leeds Conversation Club', a self-appointed association of the 'twelve leading citizens' of Leeds, founded in 1849 with the aim of being a conduit for progressive opinions on art, architecture and cultural improvement and which included leading clergymen and the journalists Edward Baines junior and Christopher Kemplay. ${ }^{48}$ The Conversation Club in turn spawned the Leeds Improvement Society, with Heaton as secretary, which aimed to promote 'architectural \& other public improvements in the town'. Heaton credited the society with persuading the town council to widen some streets and to appoint a smoke inspector, and it also promoted the idea of a Town Hall. ${ }^{49}$ Heaton's professional position was also crucial to his appointment as President of the Philosophical and Literary Association in 1868. As R. J. Morris has described, the 'Phil. and Lit.' was not only the premier cultural institution of the Leeds elite, but a key location for the social formation of that elite, particularly before the development of the 'Clubland' of the later nineteenth century. ${ }^{50}$ Heaton's record-equalling four terms as President testifies to the respect which that elite had for him, but is also revealing of the cultural capital that Heaton's

\footnotetext{
${ }^{45}$ In the last decade of Heaton's life, the family toured Italy in 1872 (Journals, iii. fos. 277ff.), Germany in 1876 (vol. v. to 19 May 1876), Brittany in 1877 (vol. v., July - Sept.), Germany and Switzerland in 1878 (vol. vi, to 12 June), and the Italian Lakes in 1879 (vol. vi., March - May).

${ }^{46}$ Gunn, Public Culture of the Victorian Middle Class, 26-7.

${ }^{47}$ Exerpted in Reid, Heaton, 145-9.

48 Journals, i. fo. 84; Reid, Heaton, 105-10.

49 Journals, i. fos. 95-7; Briggs, Victorian Cities, 160.

${ }^{50}$ Morris, Class, Sect and Party, chap. 9; Gunn, Public Culture of the Victorian Middle Class, page refs
} 
profession had accrued at a time when it had become customary for the incumbent to be either a clergyman or a qualified medical man. ${ }^{51}$

\section{Bringing Influence to Bear}

Associational life played a central role in bourgeois public culture in Britain, Europe and the United States. ${ }^{52}$ However, thanks largely to R. J. Morris, few cities have had their associational ecology examined in quite such detail as Leeds. ${ }^{53}$ In Class, Sect and Party, Morris argued that associations such as the Leeds Philosophical and Literary Society provided a neutral space in which the middle-class elite, fractured by social, religious and political divisions, could meet to discuss matters of common interest and form social and cultural bonds. ${ }^{54}$ Moreover, as well as facilitating intra-class relations, they also provided platforms for the management of relations with other classes, specifically the aristocratic elite of the West Riding and the working classes of Leeds itself. Never having served as a councillor or MP, Heaton's wider influence and reputation depended to a great extent on his position at the heart of this associational culture. While it would be almost impossible to list the full range of his engagement in this respect, we can nonetheless identify the Conversation Club, the Leeds Improvement Society, the Phil. and Lit. and, latterly, the Yorkshire Board of Education (of which he was chairman) as the most important vehicles through which Heaton was able to bring influence to bear on Leeds Town Council and the wider public. By examining some of the issues around which he chose to exert that influence, the methods by

\footnotetext{
51 The other four-time president was Rev. William Sinclair.

${ }^{52}$ See N. Bermeo and P. Nord (eds.), Civil Society before Democracy: Lessons from Nineteenth-Century Europe (Oxford, 2000); G. Morton, B. de Vries and R. J. Morris (eds.), Civil Society, Associations and Urban Places: Class, nation and culture in nineteenth-century Europe (Aldershot, 2006), including an essay by Sven Beckert on America.

${ }^{53}$ R. J. Morris, 'Organisation and Aims of the Principal Secular Voluntary Organizations of the Leeds Middle Class, 1830-1851' (unpublished PhD thesis, University of Oxford, 1971); 'Voluntary Societies and British Urban Elites, 1790-1850: An Analysis', Historical Journal, 26:1 (1983), 95-118; 'Clubs, Societies and Associations', in F. M. L. Thompson (ed.), The Cambridge Social History of Britain, iii, 395-443.

54 Morris, Class, Sect and Party, passim. See also idem. 'The Middle Class and British Towns and Cities of the Industrial Revolution', in D. Fraser and A. Sutcliffe (eds.), The Pursuit of Urban History (London, 1983), 286306; 'Middle Class Culture', in D. Fraser (ed.), A History of Modern Leeds (Manchester, 1980), 200-22; ‘A Year in the Life of the British Bourgeoisie'.
} 
which he exerted it and the arguments he employed, we can start to get a clearer picture of the nature of Heaton's civic pride, its motivations, and its limitations.

The issue of smoke prevention exemplifies Heaton's use of associational connections and professional prominence to pressurize the Council into action. This was one of the issues which particularly exercised the Leeds Improvement Society in the 1850s, probably due to Heaton's influence, as it was a cause close to his heart. In common with other major industrial towns, nineteenth-century Leeds was proverbially smoke-ridden, particularly as factories began to proliferate along the River Aire to the west. While the public health implications of smoke pollution were not always as apparent to contemporaries as they are to us, the aesthetic impact was undeniable. ${ }^{55}$ Heaton's South Parade address was vulnerable to the output of Benjamin Gott's Bean Ings mill. ${ }^{56}$ Even when they moved uphill to Claremont, a Georgian villa in the neighbourhood of Little Woodhouse in 1856, the Heatons could not avoid the problem entirely. ${ }^{57}$ In December 1865, with a local Improvement Bill making its way through parliament, Heaton became concerned that it contained no provision to deal more effectively with the consumption of smoke: a clause extending regulations on smoke consumption to furnaces used for the production of steam by dyers and ironworkers having been struck out at a council meeting on 15 December. ${ }^{58}$ Distrusting the bland assurances of the council, Heaton pithily summarised the issue: 'The fact is that the Town Council contains a large proportion of Smoke Makers, who have no wish to be disturbed or to disturb others; and it is only through strong and continued pressure from without that they can be compelled to do their duty at all in repressing the nuisance of smoke. ${ }^{59}$ Here Heaton's position as a professional man enabled him to take up a position in opposition to the manufacturing elite which dominated the town, while also obscuring his self-interest as a property owner in a potentially affected area.

The first step in mobilising 'pressure from without' was via the still active Conversation Club, where Heaton introduced his proposals for a smoke nuisance clause on 26 December. The upshot was that he and Arthur Lupton, of the wealthy and ubiquitous

\footnotetext{
${ }^{55}$ For Victorian attitudes to smoke pollution and its amelioration, Stephen Mosley, The Chimney of the World: A History of Smoke Pollution in Victorian and Edwardian Manchester (London, 2008).

${ }^{56}$ See n. 27 above.

${ }^{57}$ For the history of Claremont and Woodhouse Square, Beresford, East End, West End, 307-8, 312-13, 316-19, 323-4, 330-1, 334-6, 338; B. and D. Payne, Claremont, Leeds (Leeds, 1980).

${ }^{58} L M, 16$ Dec. 1865; see also correspondence on in $L M$ 18, 20, 26, 27 Jan. 1866.

59 Journal, ii. fo. 122.
} 
Unitarian family, were appointed as a deputation to discuss the matter with the Town Clerk. ${ }^{60}$ Satisfaction not being forthcoming, the matter was brought before a public meeting at the Philosophical Hall on 8 February 1866, described by Heaton as 'very influential' in its attendance. ${ }^{61}$ Heaton was selected as the spokesman of the deputation appointed by the meeting to bring its resolutions to the quarterly meeting of the Town Council on 15 February, and was subsequently appointed as secretary to the committee appointed to monitor the bill and ensure that satisfactory clauses were included.$^{62}$ A petition was also sent to parliament demanding action. ${ }^{63}$ The following year, Heaton collected funds to defray the cost of the campaign, though it seems to have been the Improvement Society's swan-song. ${ }^{64}$

On the face of it, this is a pattern common to civic improvement in other nineteenthcentury cities with a similar pattern of participatory democracy guided by 'leading men'. As Mary Ryan puts it in relation to the antebellum United States: 'The circuit from public meeting to petition to city hall was the pathway to many a civic project large and small., ${ }^{65}$ However, what makes the Leeds case slightly different is the orchestrating role of the Conversation Club. At the heart of the city which inspired Morris's model of the 'subscriber democracy', this clique stands out as a body whose oligarchical and patrician nature sits rather incongruously with its self-image as a body of enlightened improvers. As E. P. Hennock demonstrated in his comparison of the municipal governments of Leeds and Birmingham, while in the latter town service on the municipal council actually became more attractive to high status individuals in the second half of the nineteenth century, the reverse was generally true in Leeds. ${ }^{66}$ This, alongside Heaton's natural shyness, may have been an important reason why unaccountable associations such as the Conversation Club were more attractive to him as sources of prestige and influence than municipal service.

The Conversation Club was not the only associational platform that Heaton used to promote his views. His lecture to the Philosophical Society in January 1854 putting the case

\footnotetext{
${ }^{60}$ Ibid.

${ }^{61}$ See the $L M$ report of meeting on $8 \mathrm{Feb}$.

62 Journal, ii. fos. 125-32.

${ }^{63}$ Fully printed in $L M, 24$ Feb. 1866.

${ }^{64}$ Newspaper cutting, journal, ii. fos. 199-200.

${ }^{65}$ Ryan, Civic Wars, 106.

${ }^{66}$ Hennock, Fit and Proper Persons.
} 
for the clock-tower has already been mentioned. ${ }^{67}$ Ironically, given this episode is currently Heaton's main claim to wider fame, this lecture may not have been so influential as Reid and Briggs claimed. Heaton recorded that it was 'thinly attended', and it certainly received only cursory notice in the local press. ${ }^{68}$ When the council finally debated the tower issue in February, there was a consensus that 'public opinion' was moving behind it, with supportive articles cited from the Builder and Critic, and a canvass for voluntary subscriptions in Mill Hill Ward. ${ }^{69}$ At most Heaton's address added to a growing chorus of educated and professional opinion in favour of the tower. However, the excerpts of the lecture published by Reid are Heaton's most cogent statement of the role of great architecture as the outward expression civic pride. For Heaton, besides its utilitarian role as offices for the council, the new buildings 'are intended to present an appearance worthy of the wealth and prosperity of the town; to show that in the ardour of mercantile pursuits the inhabitants of Leeds have not omitted to cultivate the perception of the beautiful and a taste of the fine arts, and to serve as a lasting monument of their public spirit and generous pride in the possession of their municipal privileges' ${ }^{70}$

Heaton also used letters to the press as a means of pressing his views. For instance, in 1876 he wrote to the Leeds Mercury to lobby for the inclusion of a dedicated banqueting space in the projected Municipal Buildings on Calverley Street, remedying a perceived deficiency in the design of the town hall which reduced the mayor to hosting entertainments in rooms designed as offices. ${ }^{71}$ This letter was followed up by private conversations with the mayor and the chair of the building committee. ${ }^{72}$ Heaton returned to the issue in 1879 , arguing that the space being reserved for the free library (the nucleus of the current Leeds City Library) should be dedicated to this purpose. ${ }^{73}$ On this occasion Heaton's concern for the 'dignified' element of local government - that relating to ritual and display - outweighed his interest in public education. This makes more sense when we remember that public receptions and entertainments were an essential part of late-nineteenth century projections of

\footnotetext{
${ }^{67}$ Briggs, Victorian Cities, 161, 164-5; see also Kitson Clark, Leeds Philosophical and Literary Society: History of one hundred years (Leeds: Jowett \& Sowry, 1924), 65.

${ }^{68}$ Journal, i. fo. 119; Leeds Intelligencer 7 Jan. 1854; LM 7 Jan. 1854.

${ }^{69}$ LM supplement, 11 Feb. 1854.

${ }^{70}$ Reid, Heaton, 147.

${ }^{71}$ The letter is reproduced in Journals, iv. 10 April 1876; printed LM, 11 April 1876.

${ }^{72}$ Journal, iv. 10 April 1876

${ }^{73}$ Journal, vi. [n.d.] March 1879.
} 
civic pride, which were well reported in the regional and even national press. ${ }^{74}$ Equally unsuccessful was his effort to persuade the members of the Leeds Library, the town's venerable subscription library, that the institution required 'a new building suitable to the present size and wealth of the town'. This proposal, which had first emerged during Heaton's presidency of the institution, generated many contradictory resolutions in committee before being defeated at a meeting of shareholders, 'many of the members inclining to the narrow plan of endeavouring to enlarge the present inconvenient and very insecure premises. ${ }^{, 75}$

The prestige of the town and its institutions was not always the consideration uppermost in Heaton's mind when lobbying for improvements, and he was not above using his influence to further his own interests. In 1871, complaining that the latest improvement act for Leeds appeared to favour streets where councillors held property, Heaton, with no apparent sense of irony, wrote an anonymous letters to the Leeds Mercury drawing their attention to the parlous state of Swinegate, where, as he confessed in his journal, 'I own a very considerable frontage' ${ }^{76}$ Although the letter bore no immediate fruit, the Council later purchased this property for $£ 15,000$ to facilitate the widening of the street. ${ }^{77}$ This was not the only occasion when Heaton attempted to manipulate his position to his own advantage, or those of his friends. For example, during his stint on the Leeds School Board he endeavoured to promote the interests of the architect George Corson, who had carried out the alterations to Heaton's own property and who was bidding to become the Board's stipendiary architect. ${ }^{78}$ Also, despite his criticisms of mayor Sir John Barran for 'spending the Town's money so lavishly in promoting the purchase of Roundhay Park, an action of which many townsmen very much disapprove', Heaton happily profited from the sale of the Leeds Gaslight

\footnotetext{
${ }^{74}$ For instance, R. Rodger, 'The “common good” and civic promotion: Edinburgh 1860-1914', in Colls and Rodger (eds.), Cities of Ideas, 144-77.

75 Journal, v. Feb. 1877; Leeds Library Minute Book, 1800-1879, esp. 4 June 1877, 28 May 1879; Minutes of Committees, June 1874-March 1879: all minute books held by the Leeds Library; F. Beckwith, The Leeds Library, 1768-1968, $2^{\text {nd }}$ edition (1968: Leeds, 1994), 59-69.

${ }^{76}$ Journal, iii. fo. 206. The letter appeared in the Leeds Mercury, 24 June 1871, under the signature of Quietus, not Medicus, as Heaton gives it in the journal.

77 Journal, vi. Feb. 1879.

${ }^{78}$ Leeds School Board Minutes, 13 March 1873; WYAS, Leeds, LTT6/1/1/1/1/1, Fos. 372-3. Heaton was unsuccessful, though Corson later went on to design the Board's premises on Calverley Street.
} 
Company to the Corporation, though as a director he must have known that much of its plant was antiquated and in need of upgrading. ${ }^{79}$

We should not, perhaps, be surprised to find that a dose of self-interest mingled with middle-class notions of civic pride. Elsewhere, it is refreshing to find Heaton practising what he preached by using his position as a private landlord to improve the physical aspect of the town and the living conditions of its inhabitants, even at hazard to his own pocket. In 1871, he was 'making arrangements for pulling down a row of dilapidated cottages, belonging to me in Lee's Yard, Meadow Lane, and replacing them with a row of superior dwelling houses for working men's families. This, as a speculation, or pecuniary investment must be very unprofitable. But the dilapidated and insanitary condition of the old buildings seemed to require their removal. ${ }^{80}$ However, Heaton could not resist drawing attention to his disinterestedness when defending the activities of the 'health' committee of the Ladies' Honorary Council of the Yorkshire Board of Education, of which his sister Ellen was secretary. Here, he described his intention to 'convert a locality known to be insalubrious, into a health place of residence for working men', but acknowledged that 'it would be quite possible for families to frustrate his endeavours to a great extent by neglect of the simplest rules of health'. Hence, the activities of the health committee in supplying working women with lectures on basic hygiene were of the utmost value. ${ }^{81}$

\section{Civic rivalry: the 'northern university' controversy.}

Heaton's version of civic pride therefore encompassed the appearance of the town, from its grand public buildings to its humbler dwellings; a healthful environment; and the projection of a suitably dignified image. It also extended to the provision of first rate institutions.

Nowhere was Heaton's influence more lasting in this respect than in his work establishing the Yorkshire College of Science, now the University of Leeds. This institution grew from the activities of the Yorkshire Board of Education, itself a further outgrowth of the Conversation Club, which Heaton chaired. ${ }^{82}$ Opened in 1874 , the College's aim was to supply the need for

\footnotetext{
79 Journal, iii. fo. 116, iv. fo. 88; Hennock, Fit and Proper Persons, 213.

80 Journal, iii. fo. 250.

${ }^{81}$ Report of a conference held by the Ladies Council in Leeds Town Hall, taken from the LM, 13 Nov. 1872; copy of the report appended to the minutes of the Yorkshire Ladies Council of Education, 12 Nov. 1872. WYAS Leeds, WYL5045/8.

${ }^{82}$ E. Thorpe, The Right Honourable Sir Henry Enfield Roscoe (London, 1916), 53-5.
} 
higher education in scientific and technical subjects. Heaton, along with Sir Andrew Fairbairn, was tasked with raising the necessary money. ${ }^{83}$ In an anonymous article for the Leeds Mercury in 1875, Heaton was quick to mobilise inter-regional rivalry in to prise open the proverbially tight purses of the Yorkshire manufacturers: 'Yorkshire - and especially the wealthy manufacturing West Riding of Yorkshire . . ought not to rest satisfied with the results which have been hitherto laboriously attained, but should contribute liberally of their wealth and their efforts, and not rest satisfied until they have rivalled their brethren of Lancashire, and raised the Yorkshire College of Science to an equality with the Owen's College in the County of Lancashire. ${ }^{84}$ Here was regional pride in the guise of friendly competition; it would not be long, though, before the gloves came off.

The reluctance of many outside Leeds to contribute to the Yorkshire College suggests that many doubted the desirability or even possibility of inter-district co-operation, and were suspicious of a Leeds-based institution. Eventually however, money did start to come in from beyond Leeds, notably from the Bradford alpaca manufacturer, Titus Salt, which 'settled finally any question whether different districts could unite for such an object. ${ }^{95}$ However, Heaton's vision for the College was not merely regional. Defending it in May 1874, Heaton put the case in its national context. Citing comments by Lord Derby at Manchester and Dr Lyon Playfair at Edinburgh University, he pointed out the growing competition from Germany, with its advanced excellence in technical education. He concluded that 'if England was to maintain her manufacturing pre-eminence she must lose no chance: she must economise and utilise her powers and materials, and develop also her artistic power, and the arts of design to the best advantage. And it was to the colleges of science applied to industry that we must look to enable us to accomplish these important objects. ${ }^{\text {} 86}$ Moreover, given the centrality of manufacturing to Britain's economic well-being, such institutions were of importance to the whole community.

\footnotetext{
${ }^{83}$ P. R. Sharp, 'Finance', in P. H. J. H. Gosden and A. J. Taylor (eds.), Studies in the History of a University 1874-1974 (Leeds, 1975), 84-6.

${ }^{84}$ Journal, iv. 20 Aug. 1875 with cutting on the facing page; LM, 21 Aug. 1875.

${ }^{85}$ Minutes of the Yorkshire College, vol. i. 2 Feb. 1877. University of Leeds, Special Collections, Brotherton 5/C, fo. 217.

86 'Yorkshire College of Science', LM, 1 May 1874. For Derby's comments, Yorkshire Post and Leeds Intelligencer, 17 Jan. 1874.
} 
The college quickly broadened its remit, incorporating teaching in history and modern languages and shortening its title to the 'Yorkshire College'. ${ }^{87}$ However, Heaton continued to fight a long rear-guard action against the incorporation of medical teaching. It was here that his long association with the Leeds Medical School became significant, as loyalty to his profession vied with his desire to extend the opportunities of Higher Education. This became a particular issue during the debates over the establishment of a northern University, and the vexed question of the relationship the Yorkshire College would hold to it.

The origin of this dispute, in Heaton's pungent description, was 'the grasping scheme of the Owen's College, Manchester, to obtain for itself exclusive powers as a university, to confer degrees on its own students'. ${ }^{88}$ Heaton believed the young Yorkshire College could not compete with the attractions of a fully accredited University on the other side of the Pennines, given Owens College's superior financial muscle. As Chairman, it is unsurprising that Heaton took an active role in expressing the College's opposition to the proposals as they stood. However, there is no question his hostility went far beyond simply expressing the will of the Council. Not only did he become one of the leading voices of Leeds opposition to the Manchester initiative, he played an uncharacteristically public role in orchestrating opposition across the north, attending Town Council meetings in Bradford and Liverpool to put the case against the Owens College proposals, and being a member of the deputation which delivered a memorial to the Privy Council identifying the flaws in the plan. ${ }^{89} \mathrm{He}$ even addressed the National Association for the Promotion of Social Science on the issue in 1878, explaining his personal view that the establishment of an independent northern university should wait until other expedients had been tried, his preference being for an affiliation of the northern colleges with UCL. ${ }^{90}$ Accepting that he was out of step with his colleagues on this point, Heaton focussed on what was portrayed as the greedy attempt of Owens College to encompass the rewards of University status to itself at the expense of the fragile efforts to provide tertiary education facilities in other towns. As the Rev. Dr Gott put it to the Leeds Town Council: 'it was of great importance that the degree should be a north of England one,

\footnotetext{
${ }^{87}$ W.B. Stephens, 'The Curriculum', in Gosden and Taylor (eds.), History of A University, 247-310, at 249-52.

${ }^{88}$ Journal, v. Dec. 1877. For further details, F.T. Mattison, 'Government', in Gosden and Taylor (eds.), History of a University, 191-7; J. Thompson, The Owen's College: its Foundation and Growth; and its Connection with the Victoria University, Manchester (Manchester, 1886), chap. xxiii.

${ }^{89}$ Journal, v., May 1878; Minutes of the Yorkshire College, i. fos. 335, 344, 354.

${ }^{90}$ J.D. Heaton, 'The University Question Discussed by a Member of the Yorkshire College', Proceedings of the National Association for the Promotion of Social Science (1878), 357-67, at 366-7.
} 
and not bear the name of Manchester alone. In seeking this they [the Yorkshire College] were not entering into antagonism with Manchester, but Leeds must take the forefront of the battle in favour of a north of England, versus a Manchester, degree giving University. ${ }^{91}$

From one perspective, the campaign draws out the ugly side of the notion of 'civic pride', which often found expression in an intolerant form of civic rivalry. Much turned on whether the Yorkshire College itself was perceived as primarily a 'Yorkshire' or a 'Leeds' institution. The need to claim the moral high-ground necessitated the quick organisation of a consensus which thoroughly isolated Owens College. This meant tackling apostates like Halifax Town Council, whose territory occupied a dangerous border zone and which had initially supported the Owens College Scheme. Heaton and his colleagues were able to persuade them to retract this earlier support and to join the opposition. ${ }^{92}$ Such successes helped cement the Yorkshire College's claims to regional rather than local significance. ${ }^{93}$

The impact of the deputation to the Privy Council was to force Owens College to the negotiating table. The principal mediator was the Duke of Devonshire, a benefactor of both institutions, whose son, Lord Frederick Cavendish, was also the President of the Yorkshire College. The meeting, on 2 July 1878 at Devonshire House in London, is recorded in Heaton's journal. ${ }^{94}$ Heaton was scornful of the arguments of the Manchester men, particularly the suggestion that it was only right Owens College should take the leading role in the governance of any future northern university due to its greater wealth. The Yorkshire College's demands were simple: first if a new University were to exist, it should be federal in nature, with Colleges in different towns able to accede to the new organisation as and when they fulfilled the criteria for incorporation, and each College being proportionately represented on the governing body, with the vice-chancellor's position rotating amongst the constituent Colleges (the original Owen's College proposals had secured this position in perpetuity); second, reflecting this, an entirely new governing organisation should be created, having a name with no local associations, Albert University being an early favourite; thirdly, to ensure fair play there should be a significant number of government appointees on the ruling body. ${ }^{95}$

\footnotetext{
91 Yorkshire College, Council Minutes 11. Aug. 1877, fo. 280.

92 Journal, v. May 1878.

93 Thorpe, Roscoe, 80.

94 Journal, vi.

95 Yorkshire College Council Minutes, i. 23 Nov. 1877, fo. 309.
} 
The Devonshire House meeting started a process of negotiation which saw the Yorkshire College gradually accept a watered-down version of the original proposals, to Heaton's disgust. His name quietly drops out of the minutes of the 'University Committee' set up to monitor the issue, members of which, including Heaton's son-in-law Arthur Rücker, conducted the negotiations with Owen's College. ${ }^{96}$ However, his journal provided Heaton with a medium to record his views of the Council's folly:

contrary to my opinion, it was decided,- not merely no longer to oppose the Owens College in its scheme for a New Univ ${ }^{y}$, but to concede much to them, (practically everything) and to co-operate in actively promoting their scheme before the government, so that, having been at much trouble and expense to oppose their scheme, we were now to incur fresh expense $\&$ trouble in promoting what is practically the same, to our own confusion. This seemed so injudicious \& suicidal a course, that I was obliged to withdraw from all action in the University business, \& discontinued attendance at meetings upon that subject. ${ }^{97}$

He elaborated further in an entry for February 1879: the new university was to be located at Manchester, and would initially only include Owen's College, other Colleges acceding once they had met the terms. Even worse, from Heaton's perspective, they also conceded the granting of medical degrees, to which he was opposed. Significantly, when the Council debated a document to be submitted to the Privy Council in 1879 detailing its concerns around the proposed University, it struck out a clause insisting that the new institution not be allowed to grant medical degrees. ${ }^{98}$ Given that Heaton had seconded the insertion of this clause at a meeting of the University sub-committee, its omission from a key negotiating document was a powerful illustration of how his views were now being over-ridden by his fellow council members. ${ }^{99}$

The Privy Council themselves eventually excluded medical degrees on the grounds that it would be unfair to provincial medical schools such as that at Leeds, though the intimation that this was due to private lobbying from Heaton is almost certainly untrue. ${ }^{100}$

\footnotetext{
${ }^{96}$ For Rücker's frustration with his father-in-law at this time, see his letter to William Fison, 2 Dec. 1878, in Mattison, 'Government', 195.

97 Journal, vi. [n.d.] Dec. 1878.

98 Yorkshire College, Council Minute Book 2, 1878-1888, 13 Dec. 1878, fo. 15.

99 Yorkshire College, Council Committee Minutes 1878-1884, 30 Nov. 1878, fo. 18.

${ }^{100}$ For Heaton's satisfaction: Journal, vi. Feb. 1879; for the accusation of his personal involvement: Mattison, 'Government', 196; Thompson, The Owen's College, 538-9.
} 
Heaton had been on the continent at the time of the second deputation to the Privy Council, and was horrified on his return to discover the extent to which the Yorkshire College was now co-operating with its rival. ${ }^{101}$ However, the Privy Council's decision was almost certainly influenced more by memorials from the London College of Surgeons and the British Medical Association. The decision to exclude medical degrees was reversed in 1883, prompting the Yorkshire College to merge with the Leeds Medical School in $1884 .{ }^{102}$ The issue of the name was also resolved, with the name settled upon being the Victoria University. ${ }^{103}$ In February 1880, just a few months before Heaton's death from pneumonia, joint petitions and a draft Charter were presented to the House of Commons. In fulfilment of Heaton's predictions, affiliation with the Victoria University was not achieved until $1887 .{ }^{104}$

\section{Conclusions}

What this article has revealed of the extent of Heaton's influence within and beyond Leeds further justifies the historiographical shift away from cohort studies of municipal councillors, such as those of Hennock and Garrard, or the focus on other formal institutions such as vestries and the poor law, as in the work of Derek Fraser, to a more cultural approach embracing the contribution of associational culture, civic ritual and individual expertise in constructing a 'multi-centred protean structure of [urban] governance'. ${ }^{105}$ Heaton's natural domain was precisely the more informal centres of influence foregrounded by Morris, such as the Conversation Club and the 'Phil. and Lit.', while his version of civic pride was rooted to a greater extent in the kind of civic ritual and display described by Simon Gunn and Mary Ryan than in anything akin to Birmingham's 'civic gospel'. Indeed, for all his concern that the municipal council had an architectural setting worthy of the town's wealth and reputation,

\footnotetext{
101 Journal, v. 8 May 1879. There was concern on both sides of the Pennines that Heaton would write directly to the President of the Council on the issue, but according to another member of the university sub-committee this communication was never sent: Thorpe, Roscoe, 85-6.

102 S. Butler, 'A Transformation in Training: The Formation of University Medical Faculties in Manchester, Leeds, and Liverpool, 1870-84', Medical History, 30 (1986), 115-32; Anning and Walls, Leeds School of Medicine, chap. 6.

103 There is a certain irony that the University of Manchester has now revived the title of 'Victoria University', originally forced upon it by the jealousy of its northern rivals.

${ }^{104}$ Mattison, 'Government', 196, 200-2.

105 R.J. Morris, 'Governance: two centuries of urban growth', in Morris and Trainor (eds.), Urban Governance, 1-14, at 10; J. Garrard, Leadership and Power in Victorian Industrial Towns 1830-80 (Manchester, 1983); D. Fraser, Urban Politics in Victorian England: the structure of politics in Victorian Cities (Leicester, 1976).
} 
Heaton remained ambivalent about the role of democratic municipal government in promoting urban improvement. His instincts were not naturally democratic and he preferred exercising influence through a coterie such as the Conversation Club and its offshoots. The only publicly elected position he occupied, on the Leeds School Board, was the result of his failure to prevent a contested election by having the Board pre-selected by a committee of fifty of the 'leading men' of the town. ${ }^{106}$ Heaton was thereby forced to come forward on the Anglican ticket, to 'attend committee meetings, and to make speeches; and to popularize myself so far as my constitutional reticence would allow' ${ }^{107}$

This ambivalence was partly due to his apolitical nature, fostered by his connections to both the dissenting and Anglican communities and the pragmatic need for a young medical man to make his way, though in the last decade of his life the education issue increasingly forced him into the Conservative camp. ${ }^{108}$ However, it was also symptomatic of wider ambiguities in his relationship with the town council, which he sometimes saw as a useful means of promoting the prestige of Leeds, and at other times as ignorant or wasteful. When it came to improving the living standards of ordinary residents, Heaton seems to have believed more in the efficacy of private enterprise, as with his own activities as an improving landlord and his shareholding in the Artizans Dwelling Company, a profit-making organisation which promoted the building of model dwellings. ${ }^{109}$

In keeping with Hennock's findings regarding the relatively low social status of the council in Leeds, Heaton looked for more traditional markers of recognition rather than seeking prestige through elected office. His appointment to the West Riding magistrate's bench in 1871 was recorded as: 'a distinction of which I had been for some time ambitious, and the acquisition of which gave me more satisfaction than any circumstance which has occurred to me for some time'. ${ }^{110}$ Similarly, when he was became a Trustee of the Pious Uses Committee, the governing body of the Leeds Grammar School, Heaton declared: 'This is an office which I have for some time wished to hold, both as being myself an old Grammar School boy, and because it is, for the most part, confined to the more leading men in the Church circle in Leeds. ${ }^{111}$ Recognition from those he considered his peers was more

\footnotetext{
106 The controversy can be traced in the press: $L M, 25$ Oct., 8, 10-12, 14-19, 21-26 and 28-30 Nov. 1870.

${ }^{107}$ Journal, iii. fo. 138.

108 Journal, iv. fos. 196, 200-2.

109 Journal, v. 3 March 1877.

${ }^{110}$ Journal, iii. fo. 254.

111 Journal, iv. fos. 176-8.
} 
important than the approbation of his humbler townsfolk, but by the 1870 s Heaton's preferred mode of using private influence and working through voluntary association appears increasingly outdated: especially when one considers that in Birmingham, voluntary action, secular or religious, was increasingly seen as the junior partner of municipal enterprise. ${ }^{112}$

Finally, using Heaton's journals in conjunction with Gleadle's model of public subjectivity adds to the recent historiography by allowing us to access the complex matrix of identities, motivations and opportunities which drove and facilitated the public interventions of an influential yet retiring individual. They included concern for the prestige of his family and profession, his religious allegiances and moral conception of public duty, all tempered by self-interest. Such insight is not usually possible, even for relatively well-documented individuals. Perhaps most poignantly, the journals allow us to witness the tensions between Heaton's strong sense of civic duty on the one hand, and his feelings of personal underachievement and unrealised potential on the other. As he aged, the annual summaries at the close of each year increasingly alluded to thwarted ambitions. ${ }^{113}$ Heaton believed his efforts to maintain an influential public position had come at the expense of a lucrative private medical practice and he did not always believe he had made the right choice. ${ }^{114}$ Even when public recognition did come his way, there was a feeling that it was no more than his due, as when he was appointed a JP:

I found much gratification and encouragement in this appointment. I felt also that it was not undeserved in return for much public self-denying work of various kinds in which I have been concerned for many years. ${ }^{115}$ The rewards of public service could be great, but they were also intangible, and they did not come without a cost.

\footnotetext{
${ }^{112}$ Hennock, Fit and Proper Persons, 141-3

${ }^{113}$ For Heaton's pessimistic personality: Thorpe, Roscoe, 84.

${ }^{114}$ For example, Jan 1870: Journals, iii. fo. 2.

115 Journal, iii. fo. 254.
} 